\title{
OPTIMALISASI OMZET MELALUI PERENCANAAN PEMASARAN DIGITAL DAN PELATIHAN PENCATATAN KEUANGAN CUANKI KANG RAFFIE BANDUNG
}

\author{
Fia Dialysa \\ fdialysa@gmail.com \\ Mohamad Hadi Prasetyo \\ hadi.p@ekuitas.ac.id
}

SEKOLAH TINGGI ILMU EKONOMI EKUITAS

\begin{abstract}
ABSTRAK
Progam pengabdian kepada masyarakat yang dilakukan, bertujuan untuk meningkatkan omzet penjualan Cuanki Kang Raffie yang terletak di kota Bandung dengan cara pemasaran digital yang optimal dan pencatatan keuangan yang sistematis. Program pengabdian pada masyarakat ini berbentuk pelatihan serta pendampingan pada pelaku usaha untuk melihat hasil dari pembekalan keilmuan manajemen keuangan dan pemasaran di awal kegiatan. Program ini sebagai salah satu upaya meningkatkan kemampuan dan keterampilan usaha kecil agar dapat meningkatkan usahanya, serta berujung pada meningkatnya total pendapatan. Masalah yang sering dihadapi oleh para pelaku usaha diantaranya adalah tidak dilakukannya sistem pencatatan keuangan yang sistematis sehingga berdampak pada tidak terlihatnya marjin keuntungan antara modal dengan biaya yang dikeluarkan. Hal itu juga berpengaruh pada perencanaan pemasaran pada periode berikutnya. Ditambah tidak optimalnya proses komunikasi pemasaran secara digital yang dilakukan oleh pelaku usaha. Objek pengabdian kepada masyarakat ini adalah Cuanki Kang Raffie yang beralamat di Jl. Pasirlayung I No. 2 Bandung. Dengan adanya akun Instagram dan proses pencatatan keuangan yang baik, maka akan tercipta optimalisasi omzet. Sesuai dengan harapan dari pelaku usaha, bahwa dengan adanya pemasaran digital dan pencatatan keuangan yang baik, maka akan lebih mudah merumuskan strategi kedepannya.
\end{abstract}

Kata kunci: Cuanki, Digital Marketing, Pelatihan Pencatatan Keuangan.

\section{PENDAHULUAN}

Tidak sulit menemukan cuanki di Kota Bandung. Karena memang Kota Bandung merupakan salah satu kota kuliner diantara kota-kota lain di Indonesia. Bahkan bisa dikatakan bahwa cuanki merupakan kuliner khas dari Kota Kembang ini. Kesibukan yang padat dan mobilitas yang tinggi mengubah gaya hidup serta pemikiran masyarakat perkotaan yang menginginkan sesuatu yang praktis, mudah di dapat, tanpa menyita banyak waktu. Hal inilah yang menjadikan alasan terciptanya bisnis kuliner bakso cuanki instan dengan merk 'Kang Raffie".

Secara umum, cuanki adalah sejenis makanan berkuah yang sejatinya lumrah untuk disebut 'bakso Bandung". Hal tersebut ditandai dengan banyaknya para pedagang cuanki yang berasal dari kota 
Bandung atau biasa disebut Bandung Raya. Arti kata "Cuanki" itu sendiri dapat diartikan sebagai kependekan dari "Cari Uang Jalan Kaki”. Hal itu muncul karena di waktu yang terdahulu, Cuanki dijajakan dengan cara dipikul berjalan kaki. Cuanki itu sendiri merupakan sebutan makanan yang isinya terdiri dari mie, siomay goreng, siomay kukus, tahu rebus, tahu goreng dan bakso. Kuahnya berwarna bening terbuat dari kaldu ayam/daging sapi dan diberi bumbu, dengan bahan pelengkap daun bawang seledri, dan sukro kriuk. Penyajian cuanki terbilang unik, karena isian dari Cuanki tersebut direbus terlebih dahulu dalam kuah hingga siomay goreng mengembang.

Cuanki Kang Raffie mengembangkan bakso cuanki dalam bentuk instan atau siap seduh dengan mengusung konsep milenial yang serba praktis sebagai upaya untuk memanfaatkan peluang agar dapat meraih keunggulan kompetitif. Cuanki ini dikemas dalam "cup" tahan panas, dengan isian yang dikeringkan lengkap dengan bumbu serta bahan pelengkap, tinggal seduh menggunakan air panas, dan siap disajikan.

Adapun permasalahan yang dihadapi oleh Cuanki Kang Raffie yaitu perencanaan pemasaran digital yang kurang optimal dan proses pencatatan keuangan yang masih bersatu antara pendapatan usaha dan uang pribadi. Hal ini menyebabkan omzet menjadi tidak optimal. Perencanaan pemasaran digital yang kurang optimal, menyebabkan komunikasi pemasaran melalui platform digital tidak memberikan hasil yang signifikan.

Komunikasi pemasaran terpadu (integrated marketing communication) adalah sebuah konsep dari perencanaan komunikasi pemasaran yang memperkenalkan nilai tambah dari rencana komprehensif yang mengevaluasi peran strategis dari berbagai disiplin komunikasi (Kotler dan Keller, 2016). Seperti contohnya ialah periklanan umum, respon langsung, sales promotion dan mengkombinasikan disiplin-disiplin ilmu ini untuk memberikan kejelasan, konsistensi dan dampak komunikasi yang maksimal. Menurut Shimp (2014) IMC merupakan suatu proses komunikasi yang memerlukan perencanaan, penciptaan, integrasi, dan implementasi dari berbagai bentuk Marcom (iklan, promosi, penjualan, publisitas perilisan, acara-acara, dsb) yang disampaikan dari waktu ke waktu kepada pelanggan target merek dan calon pelanggan. Jadi, komunikasi pemasaran dapat dibagi menjadi tiga bagian besar, yaitu; mass communication, personal communication, dan digital communication.

Menurut Nurbiyati dan Machfoedz yang dikutip oleh Tujiono \& Karneli (2017) sales promotion adalah suatu aktivitas dan atau materi yang berfungsi sebagai persuasi langsung, yang menawarkan nilai tambah atau produk kepada penjual atau konsumen. Menurut Tjiptono dalam Rosaliana \& Kusumawati (2018) Sales Promotion merupakan segala bentuk penawaran atau insentif jangka pendek yang ditujukan bagi pembeli, pengecer atau pedagang grosir dan dirancang untuk memperoleh respons spesifik dan segera. Dalam praktiknya, sales promotion ada di platform digital. Digital Marketing dapat diartikan kegiatan marketing menggunakan berbagai media berbasis web seperti blog, website, dan sosial media. Menurut Stelzner (2012) Media sosial berpotensi untuk membantu pelaku UMKM dalam memasarkan produknya. Oleh karena itu, pentingnya digital marketing platform untuk UMKM dilakukan. Wardhana (2015) menemukan bahwa strategi digital marketing berpengaruh hingga $78 \%$ terhadap keunggulan bersaing UMKM dalam memasarkan produknya.

Permasalahan lainnya, yaitu proses pencatatan keuangan yang tidak sistematis dimana dana pribadi sang pemilik dengan profit usaha tidak dipisahkan, hal ini dapat menyebabkan kebangkrutan. Manajemen keuangan adalah suatu proses dalam pengaturan aktivitas atau kegiatan keuangan dalam suatu organisasi dimana didalamnya termasuk kegiatan perencanaan, analisis dan pengendalian terhadap kegiatan keuangan 
(Brigham dkk, 2012). Menurut Sulindawati (2017:2) manajemen keuangan merupakan aktivitas perusahaan yang berhubungan dengan usaha mendapatkan dana yang diperlukan dengan biaya yang minimal dan syarat-syarat yang paling menguntungkan beserta usaha untuk menggunakan dana tersebut seefisien mungkin. Fahmi (2016) menjabarkan bahwa ada beberapa fungsi dari manajemen keuangan yaitu (1) kegiatan mencari dana (obtain of fund) yang ditujukan untuk keputusan investasi yang menghasilkan laba, (2) kegiatan menggunakan dana (allocation of fund); dan (3) kegiatan mendistribusikan laba sebagai hasil kegiatan operasi.

Seorang manajer keuangan atau manajer umum harus dapat mengambil keputusan yang tepat dimana hubungannya nanti akan beririsan dengan tujuan dari perusahaan. Seperti diketahui secara normatif tujuan perusahaan ialah untuk meningkatkan nilai perusahaan. Tujuan ini identik dengan meminimalkan biaya modal yang harus dikeluarkan oleh perusahaan. Laporan keuangan merupakan hasil akhir proses akuntansi. Hal tersebut dapat dicerminkan melalui kinerja sebuah UMKM berdasarkan laporan keuangan yang dibuat secara periodik. Definisi laporan keuangan mengacu pada Standar Akuntansi Keuangan (SAK) adalah, laporan keuangan merupakan bagian dari proses pelaporan keuangan. Tujuan laporan keuangan adalah penyajian informasi mengenai posisi keuangan (financial position), kinerja keuangan (financial performance) dan arus kas (cash flow) dari entitas yang sangat berguna untuk membuat keputusan ekonomis dari para penggunanya (IAI, 2012:5).

Berdasarkan deskripsi tersebut, maka program pengabdian kepada masyarakat yang dilakukan diharapkan mampu meningkatkan tingkat efektivitas dan aplikasi manajemen keuangan serta perencanaan pemasaran strategis pada Cuanki Kang Raffie.

Pelaksanaan pengabdian pada masyarakat ini mempunyai tujuan dan manfaat sebagai berikut:
1. Pelatihan perencanaan pemasaran digital untuk meningkatkan brand awareness. Pelatihan ini bertujuan untuk mengembangkan strategi pemasaran digital.

2. Pelatihan aplikasi sistem pencatatan keuangan sederhana untuk memudahkan para pelaku usaha melakukan sistem pencatatan, baik pencatatan modal kerja barang persediaan maupun profit usaha.

\section{METODOLOGI PELAKSANAAN}

Adapun metode pelaksanaan kegiatan pengabdian pada masyarakat ini adalah :

1. Metode pendekatan masalah, yaitu metode pendekatan dengan diskusi antara tim pengabdian dengan pelaku usaha dengan tujuan untuk lebih mengetahui kendala dan hambatan dalam menjalankan usaha. Metode ini dilakukan dengan cara seperti $f g d$ antara tim dengan pelaku usaha. Mendengarkan apa yang mereka kerjakan, hambatan, dan harapan kedepannya. Dilakukan bulan pertama dan kedua.

2. Metode prosedur kinerja, yaitu melakukan pelatihan pencatatan kaeuangan yang berhubungan dengan manajemen keuangan dan perencanaan pemasaran digital sebagai cara untuk mengatasi persoalan promosi sebelumnya. Tim pengabdian merinci apa saja yang ingin disampaikan kepada pelaku usaha terkait penyelesaian masalah mereka. Dilakukan bulan kedua dan ketiga.

3. Metode perencanaan aktivitas, dilakukan pelatihan pencatatan tersebut yang mengarah pada manajemen keuangan dan perencanaan pemasaran digital dengan menggunakan modul dan terjun langsung ke lapangan. Membuat workshop kecil karena hanya satu orang admin keuangan dan satu orang admin pemasaran. 
Dilakukan bulan keempat dan kelima dengan periode satu bulan sekali.

4. Melakukan monitoring dan evaluasi yang dilakukan oleh tim pengabdian kepada pelaku usaha selama 3 (tiga) bulan, antara bulan ke enam sampai ke delapan.

Metode pelatihan yang dilakukan bersifat :

- Teaching, metode transfer knowledge yang dilakukan oleh tim untuk penyampaian materi kepada UMKM (peserta).

- Teach to Learn, yaitu peserta diminta untuk menceritakan apa saja yang sudah disampaikan oleh tim untuk menjawab permasalahannya. Hal ini dirasa perlu karena untuk meyakinkan bahwa peserta sudah mengerti apa yang disampaikan.

- Praktik (latihan), merupakan latihan pengaplikasian dari teori yang telah diterima selama kegiatan. Pembuatan akun instagram dan pelatihan berjualan dengan platform digital.

- Monitoring dan evaluasi. Pelaku usaha setelah 3 (tiga) bulan pelaksanaan pengabdian dipantau perkembangannya, apakah mengalami maksimalisasi omzet ataukah tidak.

\section{HASIL DAN LUARAN}

Pengabdian pada masyarakat ini berlangsung pada tanggal 2 Maret 2020, yang bertempat di Jalan Pasirlayung I No.2 Bandung, dan dimulai pada pukul 09.0012.00 WIB. Kegiatan diawali dengan pengenalan pentingnya optimalisasi omzet dalam usaha kuliner, serta penjelasan mengenai manfaat pencatatan keuangan sederhana dan manfaat perencanaan pemasaran digital.

Kemudian dilanjutkan dengan kunjungan secara langsung ke tempat produksi cuanki serta melakukan dokumentasi, wawancara dengan pemilik usaha, yang bernama Bapak Yudha. Selanjutnya, pelatihan pembukuan sederhana yang bertujuan untuk meningkatkan keterampilan dan pengetahuan, dapat memisahkan keuangan pribadi dengan usaha, serta dapat mengetahui perkembangan usaha melalui pencatatan keuangan yang baik. Kegiatan pelatihan ini dilaksanakan dua arah dan adanya sesi diskusi.

Selanjutnya, tahapan perencanaan pemasaran digital yang menitikberatkan pada pengenalan dan implementasi pemasaran digital pada bisnis (dilakukan pada saat transfer knowledge. Dalam pelatihan ini meliputi:

- Pemahaman bagaimana konektivitas dapat meningkatkan omzet bisnis. Dimulai dari penyampaian pemahaman tentang bagaimana konektivitas dalam dunia digital dilakukan.

- Pemahaman customer path dan perubahannya pada saat ini, hal ini dibutuhkan pemahaman mendalam agar tercipta target konsumen yang relevan.

- Bagaimana membangun konten pemasaran dalam platform digital.

Setelah itu pelaku usaha dibuatkan akun instagram untuk aplikasi langsung pemasran pada digital platform. Hal ini dimaksudkan juga agar meluas area penjualannya. Sesuai dengan pernjabaran dari pelaku usaha, bahwa sasarannya lebih menitikberatkan pada kaum milenial, maka dibuat akun instagram yang memang banyak kaum milenial menggunakannya. 


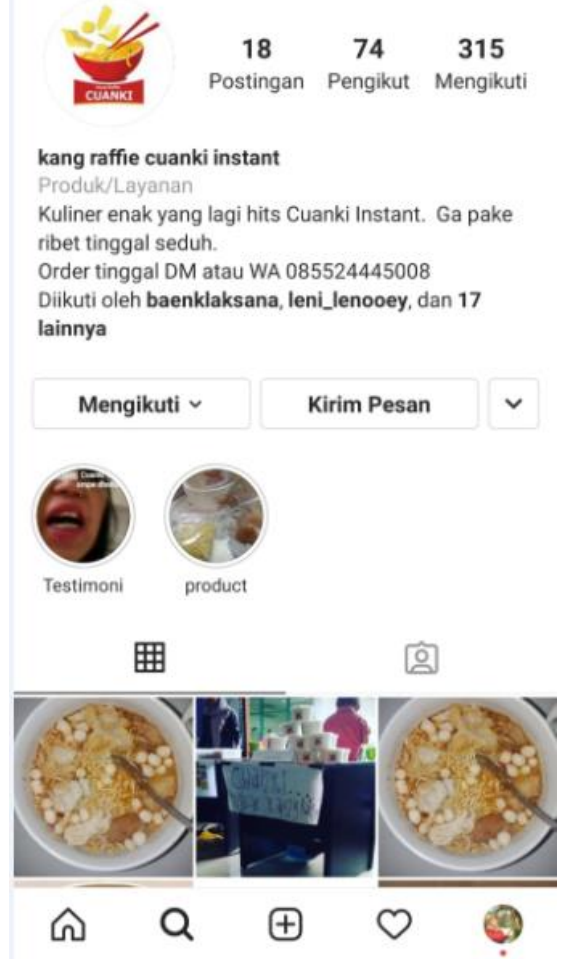

Gambar 1. Akun Instagram.

Faktor penghambat yang terjadi dalam pelatihan yang dilaksanakan adalah tidak tersedianya sarana dan prasarana fasilitas pendukung untuk menjalankan pelatihan di ruangan, akan tetapi hal tersebut tidak mengurangi semangat tim untuk memberikan materi. Faktor pendukung yang terjadi dalam pelatihan yang dilaksanakan adalah dimana peserta antusias dan semangat dalam menjalankan pelatihan dan mereka lebih sering bertanya sehingga terjadi proses diskusi. Pelatihan dan diskusi dilakukan di lapangan secara langsung agar dapat memberikan contoh secara nyata kepada peserta pelatihan. Pelatihan ini mendapatkan dukungan dari masyarakat sekitar karena pelatihan ini diketahui oleh Ketua RW/RT setempat.

Dengan adanya akun Instagram dan proses pencatatan keuangan yang baik, dengan begitu tercipta suatu strategi yang tepat demi mencapai optimalisasi omset. Sesuai dengan harapan dari pelaku usaha, bahwa dengan adanya pemasaran digital dan pencatatan keuangan yang baik, maka akan lebih mudah merumuskan strategi kedepannya.
Berikut ini merupakan dokumentasi dari kegiatan pengabdian kepada masyarakat Cuanki Kang Raffie :
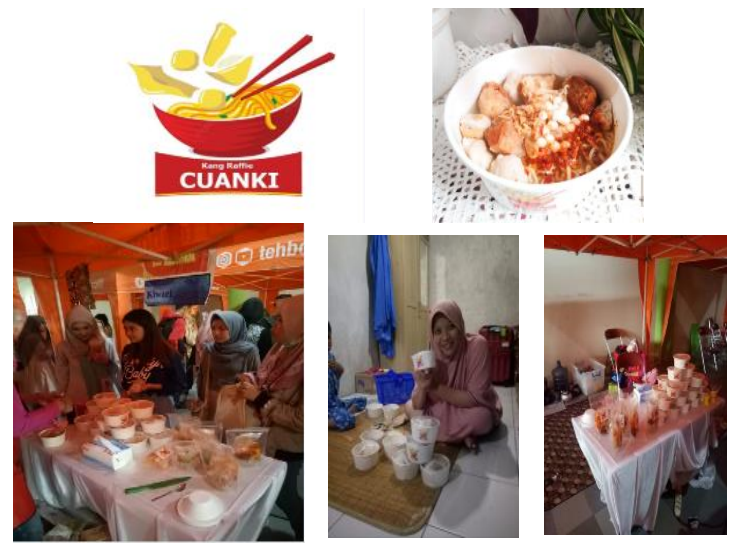

Gambar 2. Dokumentasi Cuanki Kang Raffie.

$\begin{array}{cccc}\begin{array}{c}\text { Cuanki } \\ \text { kenaikan }\end{array} & \begin{array}{c}\text { Kang } \\ \text { omzet }\end{array} & \begin{array}{c}\text { Raffie } \\ \text { sesudah }\end{array} & \begin{array}{r}\text { mengalami } \\ \text { diberikan }\end{array}\end{array}$ pelatihan, yaitu sebesar $47,5 \%$, dari $\mathrm{Rp}$ 2.576.000,00 menjadi Rp 3.800.000,00 per bulan. Pelatihan tentang bagaimana cara memaksimalkan jumlah pengikut media sosial melalui fitur promosi Instagram juga dilakukan untuk menyajikan iklan pop-up yang mendorong pengguna media sosial untuk berkunjung ke laman media sosial UKM dan mengikuti laman tersebut untuk memperoleh informasi produk terbaru. Pada awalnya, jumlah rata-rata konsumen potensial yang dimiliki Cuanki Kang Raffi tidak lebih dari 5 orang. Penggunaan media sosial sebagai alat untuk mempromoskan Cuanki meningkatkan jumlah calon konsumen potensial mencapai 18 orang dan masih akan bertambah lagi selanjutnya. Hal tersebut sudah terasa pada bulan ketiga.

\section{KESIMPULAN}

Kesimpulan dari kegiatan pengabdian pada masyarakat ini, adalah pelaku usaha sangat antusias pada pelaksanaan pelatihan yang diberikan oleh tim, sehingga tingkat efektivitas dan aplikasi manajemen keuangan serta perencanaan pemasaran strategis pada Cuanki Kang Raffie dapat meningkat sehingga dapat berdaya saing. 
Luaran dari pelaksanaan pengabdian ini dapat menjadikan Cuanki Kang Raffie memiliki pangsa pasar yang lebih luas lagi.

Cuanki Kang Raffie harus dapat memasuki pasar ekspor, agar makanan khas Indonesia dapat dikenal oleh dunia internasional.

\section{UCAPAN TERIMAKASIH}

Tim pengabdian mengucapkan Terima Kasih kepada STIE EKUITAS sebagai institusi yang sudah mendukung pelaksanaan program pengabdian kepada masyarakat ini. Juga kepada pelaku usaha, Bapak Yudha dan Ibu Tria yang sudah bersedia menjadi salah satu usaha dalam program ini, serta kepada Ketua RT 04 dan Ketua RW 02 Kompleks Pasirlayung atas dukungan dan bantuannya.

\section{DAFTAR PUSTAKA}

Brigham, E.F., dan Houston, J. (2012). Dasar-dasar Manajemen Keuangan. Buku 1, Salemba Empat, Jakarta.

Fahmi. I. (2016). Pengantar Manajemen Keuangan. Bandung: Alfabeta

Ikatan Akuntan Indonesia. (2012). Standar Akuntansi Keuangan. Jakarta: IAI

Kotler, P. \& Keller, K.L. (2016). Marketing Management $15 e$. International Edition. Prentice Hall.

Rosaliana, F., \& Kusumawati, A. (2018). Pengaruh Sales Promotion Dan Kualitas Pelayanan Terhadap Kepuasan Konsumen Serta Dampaknya Pada Minat Pembelian Ulang (Survei pada Konsumen Jasa GrabCar di Kota Malang). Jurnal Administrasi Bisnis, 60(1), 139-148.

Shimp, T., A. (2014). Komunikasi Pemasaran Terpadu Dalam

Periklanan dan Promosi. Jakarta: Salemba Empat.

Stelzner, (2012). How Marketers Are Using Social Media to Grow Their Business. Social Media Marketing Industry Report.
Sulindawati, E.L.N. (2017). Manajemen Keuangan Sebagai Dasar Pengambilan Keputusan Bisnis. Cetakan Kesatu. Jakarta: PT. Raja Grafindo Persada.

Tujiono, T., \& Karneli, O. (2017). Pengaruh Sales Promotiondanservice Qualityterhadap Minat Beli Konsumen Fast Food (Kasus Penjualan Produk Kfcpada Kfc Metropolitan City Pekanbaru) (Doctoral dissertation, Riau University).

Wardhana, A. (2015, August). Analisis faktor-faktor pembentuk service recovery pada top brand perusahaan penyedia jasa rental mobil di Indonesia berdasarkan persepsi pelanggan korporasi. In Prosiding Seminar Nasional Penelitian dan Pengabdian pada Masyarakat Sosial, Ekonomi dan Humaniora (pp. 1522).ISSN 2089-3590. EISSN 23032472. 